\title{
THE CLINICAL EFFICACY AND SAFETY OF SOMATOSTATIN AND THROMBIN COMBINED WITH OMEPRAZOLE FOR THE TREATMENT OF ACUTE UPPER GASTROINTESTINAL BLEEDING
}

\author{
HUI DONG *, FENG-JIE LI, AI-CHUN JIN \\ Department of Emergency Internal Medicine, Luhe Hospital of Capital Medical University, Beijing 101149, China
}

*corresponding author: dongh728@163.com

Manuscript received: March 2021

\begin{abstract}
The present study aimed to investigate the clinical efficacy and safety of somatostatin and thrombin combined with omeprazole for the treatment of 64 patients with acute upper gastrointestinal bleeding. 128 patients with acute upper gastrointestinal bleeding in our hospital between January 2015 and May 2017 were enrolled. Patients were randomly divided into two groups according to a random number table: observation group and control group $(\mathrm{n}=64$, each). The control group received omeprazole; the observation group received somatostatin and thrombin. The total effective rate of the observation group was $93.75 \%$, significantly higher than that of the control group $(78.12 \%, \mathrm{p}<0.05)$; the time for haemostasis and hospitalisation in the observation group were significantly shorter than in the control group $(\mathrm{p}<0.05)$; the haemoglobin (HGB) after treatment in the observation group significantly increased when compared with the control group $(\mathrm{p}<0.05)$; the adverse reaction rates in the observation group was $10.94 \%$; the difference was not statistically significant when compared with the control group $(7.81 \%, \mathrm{p}>0.05)$. Somatostatin and thrombin combined with omeprazole for treatment of acute upper gastrointestinal bleeding has a significant therapeutic effect and less acute adverse reactions. It is a safe and effective treatment option, and it may be used in clinical practice.
\end{abstract}

\section{Rezumat}

Studiul și-a propus investigarea eficacității și siguranței clinice a somatostatinei și trombinei combinate cu omeprazol pentru tratamentul unor pacienți cu hemoragie gastrointestinală superioară acută. Au fost înrolaţi 128 de pacienţi cu sângerare gastrointestinală superioară acută, spitalizați în perioada ianuarie 2015 - mai 2017. Pacienții au fost împărțiţi aleatoriu în două grupuri: grup de observație și grup control $(n=64$ pacienți, fiecare). Grupul de control a primit tratament cu omeprazol, iar grupul de observație a primit tratament cu somatostatină și trombină în plus față de grupul control. Rata de eficacitate totală a grupului de observație a fost de 93,75\%, semnificativ mai mare decât cea a grupului control $(78,12 \%, \mathrm{p}<0,05)$; timpul de hemostază și spitalizare în grupul de observație au fost semnificativ mai mici decât în grupul control ( $\mathrm{p}<0,05)$; hemoglobina (HGB) după tratament, în grupul de observație a crescut semnificativ în comparație cu grupul control ( $\mathrm{p}<0,05)$; incidența reacțiilor adverse în grupul de observație a fost de 10,94\%; diferența nu a fost semnificativă statistic în comparație cu grupul control $(7,81 \%, p>0,05)$. Somatostatina şi trombina combinate cu omeprazol pentru tratamentul hemoragiei gastrointestinale superioare acute au efecte semnificative și reacții adverse acute mai puține, fiind o opțiune de tratament sigură și eficientă.

Keywords: acute upper gastrointestinal bleeding, omeprazole, somatostatin, thrombin, clinical efficacy

\section{Introduction}

Acute upper gastrointestinal bleeding (UGIB) refers to the bleeding caused by gastrointestinal lesions above the Treitz ligament. The common diseases causing it are: bleeding caused by the rupture and varices of oesophageal veins, emergency ulcers, gastric and duodenal ulcers, gastric mucosal lesions and biliary bleeding [1]. Bleeding caused by jejunal lesions after gastrojejunostomy also belongs to this scope [2]. The onset of UGTB shows an aging trend [3]. The risk of death of UGIB increases six times in patients over 75 years of age [4, 5]. UGIB is characterized by sudden onset, rapid change of conditions and high fatality rate [6]. Patients with unstable haemodynamic have higher mortality rates $[7,8]$. A study reported that if acute massive haemorrhage occurred, the mortality rate was approximately 10\% [9]. Therefore, rapid and effective control of bleeding is the key measure to save UGIB patients' lives. Large sample analysis of UGIB clinical data is of great value for improving national health [10]. Omeprazole is a commonly used drug in the treatment of UGB in clinical applications. Its efficacy has been confirmed by many clinical trials, but there are still some patients with unsatisfactory treatment results. Our study aimed to assess the therapeutic potential of omeprazole combined with somatostatin and thrombin in acute UGB.

\section{Materials and Methods}

Study design

A total of 128 patients with acute UGIB admitted to the Department of Emergency Internal Medicine, Luhe 
Hospital of Capital Medical University, Beijing, China, from January 2015 to May 2017 were enrolled in the study. These patients were divided into two groups according to a random number table: observation group and control group ( $n=64$, each group). In the observation group, 41 patients were male and 23 patients were female. The age range of these patients was 20 - 70 years old, with an average age of $43.55 \pm$ 8.12 years old. Causes of bleeding: 31 patients had gastric ulcer; bleeding was induced by duodenal ulcers in 17 patients, induced by haemorrhagic gastritis in eight patients, and induced by oesophagogastric varices rupture in eight patients. Clinical symptoms: 38 patients had simple melena; 27 patients had melena complicated with hematemesis. In the control group, 38 patients were male and 26 patients were female, the age range of these patients was 22 - 74 years old, with an average age of $44.86 \pm 8.75$ years old. Causes of bleeding: gastric ulcers in 32 patients, duodenal ulcers in 16 patients, haemorrhagic gastritis in nine children, and oesophagogastric varices rupture in seven patients. Clinical symptoms: 35 patients had simple melena, 40 patients had melena complicated with hematemesis. The differences in age, gender, causes of bleeding and clinical symptoms between the two groups were not statistically significant ( $p$ > 0.05 ); hence, the two groups were comparable.

Inclusion and exclusion criteria

Inclusion criteria: (1) Patients with symptoms of UGIB such as melena, hematemesis and abdominal pain within 12 hours and stable vital signs; (2) no haemostatic drugs were used within 24 hours before admission, no drug to inhibit gastric acid secretion was used in the preceding week; (3) the age ranged within 18 - 80 years old; (4) patients or their family members were voluntary enrolled; all patients or their family members have provided an informed consent. This study was approved by the Ethics Committee of our hospital.

Exclusion criteria: (1) Patients with a history of subtotal gastrectomy and patients with digestive tract tumours; (2) patients with severe complications such as pyloric obstruction or massive haemorrhage; (3) patients with severe heart, liver, lung, kidney and other organ dysfunctions; (4) patients with cerebrovascular diseases, severe trauma, respiratory bleeding and haematological diseases; (5) patients with melena caused by drugs or food and bleeding from the mouth, nose, throat and respiratory tract; (6) patients with incomplete data so that curative effect statistics could not be carried out.

Methods

After admission, patients in both groups received basic treatment to maintain the stability of vital signs, including symptomatic treatment such as vital signs monitoring, fasting and fluid deprivation, maintenance of airway patency and internal environment stability, active blood volume supplementation, adjustment of water and electrolyte disorders. A low-temperature liquid or semi-liquid diet was given to patients $24 \mathrm{~h}$ after hematemesis stopped. Patients in the control group were intravenously dripped with $40 \mathrm{mg}$ of omeprazole $+100 \mathrm{~mL}$ of saline twice a day for five days. On the basis of the treatment in the control group, patients in the observation group continued to be intravenously pumped with $3.0 \mathrm{mg}$ of somatostatin, which was diluted to $500 \mathrm{~mL}$ with $0.9 \%$ sodium chloride solution at a dosage rate of $40 \mathrm{~mL} /$ hour for five days and were intra-gastrically injected with $500 \mathrm{IU}$ of thrombin, which was diluted with $20 \mathrm{~mL}$ of $0.9 \%$ sodium chloride solution three times a day, until hematemesis was stopped. During the treatment, no other drugs were used in both groups. No strong tea, coffee, spicy food, smoking and alcohol were allowed.

Before and after treatment, the changes in clinical symptoms and vital signs, respiration, heart rate, blood pressure and continuous electrocardiogram monitoring indexes were observed. The changes in urine volume, haematochezia, hematemesis and haemoglobin (HGB) levels were observed.

Improvement of gastrointestinal lesions was observed by gastroscopy. Liver and kidney function examination, routine blood and urine tests and electrocardiogram were performed before and after treatment, and the determination of whether or not adverse reactions occurred in patients was observed and asked.

Curative effect standard

Criteria for bleeding stopping: (1) heart rate ranged within 60 - 100 beats/min; (2) blood pressure was > $90 / 60 \mathrm{mmHg}(1 \mathrm{mmHg}=0.133 \mathrm{kPa})$; (3) there were no symptoms of melena or hematemesis; and (4) there was no decrease in haematocrit and HGB level.

Clinical curative effect. Excellent: within $24-48$ hours after treatment, no active bleeding occurred, haematochezia or hematemesis stopped, gastric tube drainage fluid was clear and bloodless, the pulse and blood pressure were stable, and HGB was stable or increased. Effective: within $48-72$ hours after treatment, bleeding was stopped, gastric tube drainage fluid was bloodless, blood pressure and heart rate were stable, HGB did not decrease. Ineffective: after $72 \mathrm{~h}$ of treatment, there were still melena and hematemesis, blood pressure and heart rate were unstable, the gastric tube drainage fluid was still bright red or dark red, the blood volume was continuously decreasing. The total effective rate was expressed as (excellent cases + effective cases)/total number of cases $\times 100 \%$.

Statistical analysis

Data were statistically analysed using statistical software SPSS18.0. Measurement data were expressed as mean \pm standard deviation $(\mathrm{x} \pm \mathrm{SD})$ and compared using t-test. Count data were expressed as percentage (\%) and compared using $\chi^{2}$ test. $\mathrm{p}<0.05$ was considered statistically significant. 
FARMACIA, 2021, Vol. 69, 6

\section{Results and Discussion}

Comparison of clinical curative effect between two groups of patients

The excellent rate and total effective rate were significantly higher in the observation group than in the control group; the differences were statistically significant $(\mathrm{p}<0.05$, Table I).
Comparison of haemostatic time and hospitalization time between the two groups

The mean haemostatic time and hospitalization time were significantly shorter in the observation group than in the control group; the differences were statistically significant $(\mathrm{p}<0.05$, Table II).

Table I

Comparison of clinical curative effect between the two groups of patients

\begin{tabular}{lccc}
\hline \multicolumn{1}{c}{ Index } & Observation group & Control group & p value \\
\hline $\mathrm{N}$ & 64 & 64 & \\
Male/Female & $41 / 23$ & $38 / 26$ & $>0.05$ \\
Age (Years) & $43.55 \pm 8.12$ & $44.86 \pm 8.75$ & $>0.05$ \\
Cause of bleeding & & & $>0.05$ \\
$\quad$ Gastric ulcer, duodenal ulcer & $31(48.44 \%)$ & $32(50.00 \%)$ & \\
$\quad$ Duodenal ulcer & $17(26.56 \%)$ & $16(25.00 \%)$ & \\
$\quad$ Hemorrhagic gastritis & $8(12.50 \%)$ & $9(14.06 \%)$ & \\
$\quad$ Esophageal and gastric varices & $8(12.50 \%)$ & $7(10.94 \%)$ & \\
Clinical conditions & & & \\
$\quad$ Black stool only & $31(59.38 \%)$ & $35(54.69 \%)$ & \\
$\quad$ Black stool with hematemesis & $27(42.19 \%)$ & $29(45.31 \%)$ & \\
Excellent rate (n(\%)) & $45(70.31)$ & $21(32.81)$ & $<0.05$ \\
Effective rate (n(\%)) & $15(23.44)$ & $29(45.31)$ & $<0.05$ \\
Invalid rate $(\mathrm{n}(\%))$ & $4(6.25)$ & $14(21.88)$ & $<0.05$ \\
Total effective rate $(\mathrm{n}(\%))$ & $60(93.75)$ & $50(78.12)$ & $<0.05$ \\
\hline
\end{tabular}

Table II

Comparison of haemostatic time and hospitalization time between the two groups

\begin{tabular}{lccc}
\hline \multicolumn{1}{c}{ Groups } & Cases $(\mathbf{n})$ & Haemostatic time $(\mathbf{h})$ & Hospitalization time (d) \\
\hline Observation group & 64 & $18.11 \pm 4.48$ & $3.41 \pm 2.12$ \\
Control group & 64 & $32.65 \pm 7.24$ & $5.68 \pm 2.39$ \\
$\chi^{2}$ & & 13.662 & 5.684 \\
p value & & $<0.05$ & $<0.05$ \\
\hline
\end{tabular}

Comparison of HGB between two groups before and after treatment

The difference in the level of HGB between the two groups before treatment was not statistically significant $(p>0.05)$. After five days of treatment, HGB levels in both groups were significantly higher than those before treatment, which was significantly higher in the observation group than in the control group; the difference between the two groups was statistically significant $(\mathrm{p}<0.05$, Table III).

Table III

Comparison of HGB levels between the two groups before and after treatment

\begin{tabular}{lccc}
\hline \multicolumn{1}{c}{ Groups } & Cases $(\mathbf{n})$ & Before treatment & After treatment \\
\hline Observation group & 64 & $92.35 \pm 15.44$ & $115.23 \pm 11.34$ \\
Control group & 64 & $93.45 \pm 11.89$ & $103.72 \pm 13.56$ \\
$\chi^{2}$ & & 0.452 & 5.209 \\
p Value & & $>0.05$ & $<0.05$ \\
\hline
\end{tabular}

Comparison of adverse reactions between two groups During treatment, in the observation group, palpitation occurred in two patients, short-term vertigo occurred in two patients and nausea occurred in three patients; the adverse reaction rate was $10.94 \%$ (7/64). During treatment, in the control group, palpitation occurred in one patient, short-term vertigo occurred in two patients and nausea occurred in two patients; the adverse reaction rate was $7.81 \%(5 / 64)$.
No abnormalities were found in liver and kidney function tests and routine blood and urine tests in both groups. The above-mentioned adverse reactions were all alleviated after symptomatic treatments. The difference in the adverse reaction rate between groups was not statistically significant $\left(\chi^{2}=0.267, \mathrm{p}>0.05\right)$ (Table IV). 
Comparison of adverse reactions between two groups

\begin{tabular}{lccc}
\hline \multicolumn{1}{c}{ Index } & Observation group & Control group & p value \\
\hline $\mathrm{N}$ & 64 & 64 & \\
Total adverse reaction & $7(10.94 \%)$ & $6(7.81 \%)$ & $>0.05$ \\
$\quad$ Palpitation & $2(3.13 \%)$ & $1(1.56 \%)$ & \\
$\quad$ Short-term vertigo & $2(3.13 \%)$ & $2(3.13 \%)$ & \\
$\quad$ Nausea & $3(4.69 \%)$ & $2(3.13 \%)$ & \\
$\quad$ Liver dysfunction & 0 & 0 & \\
Kidney dysfunction & 0 & 0 & \\
\hline
\end{tabular}

Acute UGIB is a common clinical critical illness. The main clinical symptoms are sudden massive hematemesis and melena, accompanied by decreased erythrocyte haematocrit, haemoglobin and blood pressure in varying degrees. Acute UGIB is a critical condition and entails more complications. It extremely easily causes liver and kidney failure and even haemorrhagic shock; if haemostasis is not performed timely and effectively, it will threaten patient's life and safety [2]. Therefore, once the symptoms of UGIB are found, quick and effective haemostasis and rescue measures should be given, and bleeding should be controlled with drugs as soon as possible after this starts, in order to prevent haemorrhagic shock, to find out the causes of bleeding in time and directly create favourable conditions for further treatment. At present, there are many drugs in the treatment of UGIB in clinic, but the curative effects are diverse. It is necessary to find a quick and effective treatment option or drug for haemostasis.

The causes of UGIB are more complicated; digestive system ulcer, acute gastric mucosal injury, oesophageal rupture and gastric varices rupture caused by liver cirrhosis are the most common in clinical practice. Gastric venous rupture usually leads to more severe bleeding and a higher mortality rate than oesophageal varices [11]. The mortality rate of first bleeding of oesophageal and gastric varices bleeding (EGVB) is up to $25-50 \%[12,13]$. Studies revealed that peptic ulcer was the most common cause of UGIB, followed by oesophageal varices and acute gastric mucosal lesions [14]. A large number of previous studies revealed that duodenal ulcer was the most common aetiology of peptic ulcer [15], especially in the case of excessive gastric acid secretion, where it was more likely to occur. Pepsinogen can be activated by gastric acid to produce pepsinase in acidic environment, to rapidly digest blood clots. Additionally, platelet aggregation is also affected by acidic conditions; thereby, the haemostasis function of digestive system is affected [4]. Therefore, in the clinical therapeutic process, acid-making agent is often used to increase the $\mathrm{pH}$ value in stomach and in combination with haemostatic drugs to achieve the purpose of haemostasis. Increasing the $\mathrm{pH}$ value of gastric secretion is conducive to reduce coagulation and lysis under the influence of pepsin, shorten coagulation time, promote platelet aggregation, delay the dissolution of clots and promote haemostasis [5]. A recent study revealed that intravenous drip of omeprazole could significantly reduce the 24-hour gastric acidity, enhance the haemostatic effect and reduce the mortality rate [16]. Omeprazole is a commonly used proton pump inhibitor in clinical practice. It can selectively act on the cell membrane and inhibit the activity of $\mathrm{H}^{+}-\mathrm{K}^{+}$-ATPase in order to produce strong acid-inhibiting effect, thus increasing the $\mathrm{pH}$ value in the stomach. In an alkaline environment, it promotes blood coagulation, thus, fast and effective haemostasis [6]. A clinical trial revealed that omeprazole could rapidly and effectively reduce the nocturnal and 24-hour gastric acidity of patients, maintain the $\mathrm{pH}$ value around 3 - 4, thereby improving the symptoms of gastric acid reflux of the oesophagus [17]. Omeprazole can strongly inhibit gastric acid secretion, so it is widely used in the treatment of gastroesophageal reflux and peptic ulcer. Omeprazole can inhibit gastric acid approximately 20 times stronger than an $\mathrm{H}_{2}$ receptor antagonist and has no obvious side effects and is safe and reliable [8]. In addition, omeprazole can produce a negative feedback effect and induce hypergastrinaemia, in turn increasing the blood flow of gastric mucosa, then promoting the repair of ulcer and erosion wounds and promoting the formation of blood scab, to exert a haemostatic effect. Therefore, using omeprazole in the treatment of acute UGIB can effectively inhibit gastric acid secretion, protect the bleeding surface from irritation of gastric acid, and can also trigger the automatic haemostasis mechanism of the body, effectively promoting platelet aggregation and inhibiting the digestion after its aggregation and promoting blood agglutination, thereby exerting a haemostatic effect [9].

Somatostatin is a synthetic cyclic 14-amino acid peptide, having the same structure and physiological effects as natural somatostatin, which can effectively inhibit the production and release of a series of vasodilator peptides such as vasoactive peptide [10]. In addition, it can selectively act on visceral vessels to promote vasoconstriction, reduce visceral blood flow, in turn reducing the symptoms of portal hypertension. However, it has no significant effect on systemic haemodynamics. Somatostatin can inhibit the secretion and release of pepsin and peptic acid, 
effectively protecting gastric mucosa and epithelial cells, thus reducing the haemolysis effect of pepsin and peptic acid on blood clots, exerting a synergistic haemostasis effect [11]. Hutchinson et al. revealed that [18] the use of somatostatin can increase the pressure of lower oesophageal sphincter, promotes the effective contraction of the lower oesophageal venous plexus, in turn reducing the blood flow in the varices vein of the oesophagus, and promoting the contraction of blood clots and the agglutination of platelets, which has significant effects on UGIB caused by many factors. Thrombin is an enzymatic haemostatic, is mainly extracted from the venom of the Brazilian spearhead snake, separated and purified. It does not contain toxic components such as neurotoxins. In normal blood vessels, thrombin has no thrombokinase-like effect and plays only its thrombin-like role. When vascular skin lesions occur, both thrombokinase-like and thrombin-like effects can be exerted [13]. Thrombin can stimulate endogenous and exogenous coagulation function after application. Thrombin can directly act on fibrinogen in the blood and promote the conversion of fibrinogen into fibrin, thereby accelerating the coagulation of blood, thus having the effect of haemostasis and coagulation [19, 21]. Different from other haemostatics, thrombin is highly selective and targeted; it can stop bleeding at the site of bleeding, cannot activate the stabilizing factor of fibrin, and cannot affect the platelet aggregation and digestion in other sites of the blood vessel. Therefore, its haemostatic effect is fast and effective $[14,20]$. When it reaches the damaged site of the blood vessel, it can quickly produce small thrombus that fills the damaged site, and block the bleeding process. Van Geffen et al. revealed that [22] thrombin can promote mitosis of epithelial cells in order to facilitate wound healing, thereby exerting a haemostatic effect. The present study revealed that the combination of these three drugs could exert a haemostatic effect through different haemostatic mechanisms. The results of the present study revealed that in patients in the observation group who were treated with somatostatin and thrombin combined with omeprazole, the total effective rate was $93.75 \%$, which increased significantly when compared with the control group (78.12\%), with the mean haemostatic time and hospitalization time significantly shorter in the observation group than in the control group. The investigators consider that the combination of three drugs can improve the targeting of haemostasis, thereby stopping bleeding more quickly and improving the haemostatic effect. After treatment, HGB levels in both groups were significantly higher than those before treatment, but the level increased more significantly in the observation group than in the control group. Our results suggest that the combination of drugs is helpful to enhance the haemostatic effect. Adverse reaction monitoring revealed that the adverse reaction rate in the observation group was $10.94 \%$, which was not significantly higher when compared with the control group $(7.81 \%)$. The adverse reaction rate was slightly higher in the observation group as compared to the control group, because the patients' compliance to the doctor's advices was poor and the body position was often changed in the observation group due to the rapid recovery of the patients. In addition, the stimulation of the gastric mucosa by $20 \mathrm{~mL}$ saline was another reason. The adverse reactions of the patients were significantly improved after the administration of metoclopramide. Our results revealed that the combination of three drugs does not increase the incidence of adverse reactions.

\section{Conclusions}

Somatostatin and thrombin combined with omeprazole in the treatment of acute UGIB can shorten the haemostatic time and the hospitalization, quickly and effectively stop bleeding, and has few adverse reactions, thereby making it a safe and reliable.

\section{Conflict of interest}

The authors declare no conflict of interest.

\section{References}

1. Foley RN, Parfrey PS, Sarnak MJ, Epidemiology of cardiovascular disease in chronic renal disease. $J$ Am Soc Nephrol,, 2013; 9(12 Suppl): S16-23.

2. Prosst RL, Kratt T, A randomized comparative trial of OTSC and Padlock for upper GI hemostasis in a standardized experimental setting. Minim Invasive Ther Allied Technol., 2017; 26(2): 65-70.

3. Langner I, Mikolajczyk R, Garbe E, Regional and temporal variations in coding of hospital diagnoses referring to upper gastrointestinal and oesophageal bleeding in Germany. BMC Health Serv Res., 2011; 11: 193: 1-7.

4. Wierzchowski P, Dabrowiecki S, Szczesny W, Urgent endoscopy in elderly patients with nonvariceal upper gastrointestinal bleeding. Videochir Inne Tech Maloinwazyjne, 2012; 7(4): 246-250.

5. Wang CY, Qin J, Wang J, Sun CY, Cao T, Zhu $\mathrm{DD}$, Rockall score in predicting outcomes of elderly patients with acute upper gastrointestinal bleeding. World J Gastroenterol., 2013; 19: 3466-3472.

6. Paspatis GA, Matrella E, Kapsoritakis A, Leontithis C, Papanikolaou N, Chlouverakis GJ, Kouroumalis E, An epidemiological study of acute upper gastrointestinal bleeding in Crete, Greece. Eur J Gastroenterol Hepatol., 2000; 12(11): 1215-1220.

7. Tang Y, Shen J, Zhang F, Zhou X, Tang Z, You T, Scoring systems used to predict mortality in patients with acute upper gastrointestinal bleeding in the ED. Am J Emerg Med., 2018; 36(1): 27-32.

8. Weng SC, Shu KH, Tarng DC, Tang YJ, Cheng CH, Chen CH, Yu TM, Chuang YW, Huang ST, Sheu $\mathrm{WH}, \mathrm{Wu} \mathrm{MJ}$. In-hospital mortality risk estimation in patients with acute nonvariceal upper gastrointestinal 
bleeding undergoing hemodialysis: a retrospective cohort study. Ren Fail., 2013; 35(2): 243-248.

9. Sayana H, Yousef O, Clarkston WK, Massive upper gastrointestinal hemorrhage due to invasive hepatocellular carcinoma and hepato-gastric fistula. World J Gastroenterol., 2013; 19(42): 7472-7475.

10. van Leerdam ME, Epidemiology of acute upper gastrointestinal bleeding. Best Pract Res Clin Gastroenterol., 2008; 22(2): 209-224.

11. Lo GH, Endoscopic treatments for portal hypertension. Hepatol Int., 2018; 12(Suppl 1): 91-101.

12. de Franchis R, Expanding consensus in portal hypertension: Report of the Baveno VI Consensus Workshop: Stratifying risk and individualizing care for portal hypertension. J Hepatol., 2015; 63(3): 743-752.

13. McCarty TR, Bakhit M, Rustagi T, Isolated Gastric Varices and Use of Balloon-occlusive Retrograde Transvenous Obliteration: A Case Report and Literature Review. J Gastrointestin Liver Dis., 2016; 25(1): 115-117.

14. Rockey DC, Hafemeister AC, Reisch JS, Acute on chronic gastrointestinal bleeding: a unique clinical entity. J Investig Med., 2017; 65(5): 892-898.

15. Raptopoulou M, Papatheodoridis G, Antoniou A, Ketikoglou J, Tzourmakliotis D, Vasiliadis T, Manolaki N, Nikolopoulou G, Manesis E, Pierroutsakos I, Epidemiology, course and disease burden of chronic hepatitis B virus infection. HEPNET study for chronic hepatitis B: a multicentre Greek study. J Viral Hepat., 2009; 16(3): 195-202.

16. Simnon-Rudler M, Massard J, Bernard-Chabert B, Di Martino V, Ratziu V, Poynard T, Thabut D, Continuous infusion of high-dose omeprazole is more effective than standard-dose omeprazole in patients with highrisk peptic ulcer bleeding: a retrospective study. Aliment Pharmacol Ther, 2007; 25: 949-954.

17. Lohsiriwat D, Saejong R, Lohsiriwat V, Tongsai S, Thamlikitkul V, Comparison of the efficacy and safety between generic intravenous omeprazole (Zefxon) and original omeprazole (Losec) in the adjunct treatment of non-variceal upper gastrointestinal bleeding in Siriraj Hospital. J Med Assoc Thai., 2011; 94(11): 1357-1364.

18. Hutchinson JM, Jennings JSR, Jones RL, Long-acting somatostatin analogue therapy in obscure-overt gastrointestinal bleeding in noncirrhotic portal hypertension: a case report and literature review. Eur J Gastroenterol Hepatol., 2010; 22(6): 754-758.

19. Rotondano G, Epidemiology and diagnosis of acute nonvariceal upper gastrointestinal bleeding. Gastroenterol Clin North Am., 2014; 43(4): 643-663.

20. Cîrstea IM, Mîndrilă B, Țieranu E, Țieranu LM, Istrătoaie O, Militaru C, Donoiu I, Overview of nonvitamin K oral anticoagulants. Farmacia, 2020; 68(2): 206-212.

21. Dewan KR, Patowary BS, Bhattarai S, A study of clinical and endoscopic profile of acute upper, gastrointestinal bleeding. Kathmadu Univ Med J (KUMJ.), 2014; 12(45): 21-25.

22. Van Geffen M, Menegatti M, Loof A, Lap P, Karimi M, Laros-van Gorkom BAP, Brons P, Van Heerde WL. Retrospective evaluation of bleeding tendency and simultaneous thrombin and plasmin generation in patients with rare bleeding disorders. Haemophilia; 2012; 18(4): 630-638. 